\title{
Introduction to Scaling the Social Enterprise
}

A persistent question we get asked as faculty members, advisors, researchers and investors, is why some social enterprises (SEs) scale, while others do not. Roadblocks to scaling can be due to a variety of factors, rendering many nonprofits incapable of responding "adequately to the post-2008 conditions of extreme environmental uncertainty and stability" ${ }^{1}$ most acutely felt since a reduction in funding for social services during the Ronald Reagan US presidency. Indeed, research shows that US-based nonprofits have had difficulty breaking the one million dollar revenue barrier for years, with only 8 percent holding an operating budget of one million or more. ${ }^{2}$ Nonprofits are not alone in experiencing challenges around growth; of the 28 million for-profit firms in the US, only 4 percent have had annual revenue above one million. ${ }^{3}$ Scaling has indeed become the touchstone question that we attempt to address in our book, prescient not only for students and scholars, but also for those working day in and day out at their social startups alike. Of course, at the writing of this book, the onset of COVID-19 has only exacerbated the divide between those in need and the under-resourced SEs trying to serve them. Out of the pandemic, though, have also come some novel ways in which SEs have responded and pivoted. In this book, we share those findings as well.

Given that most organizations, for-profit or nonprofit, do not achieve scale, we ask, why has this topic taken on so much importance, now? Research shows that while in the past, smaller nonprofits might have been able to exist at a steady state of equilibrium, this is unlikely to continue. In fact, going forward, SEs that lack scale are much more likely to be "left behind" when it comes to funding, while those that do scale are predicted to garner a disproportionate amount of society's available resources in both financial and human capital. ${ }^{4}$ Within the last decade, funders of SEs, including social venture capital investors, foundations, and government entities, have begun to select their investments and donations based on an organization's ability to scale. ${ }^{5}$ This is due to the fact that funders are often seeking more efficient ways to solve society's ills, preferring to back fewer SEs, with a bias towards those that can demonstrate larger yet leaner - or more efficient - operations. In the words of former US President Barack Obama: "Instead of wasting taxpayer money on programs that are obsolete or ineffective, government should be seeking out creative, results-oriented programs ... and helping them replicate their efforts across America."6

Management research has also shown ${ }^{7}$ that scaling increases a firm's likelihood of survival. Phillips (2006) notes that, "Growth is important to ensuring that the enterprise moves out of the gestation period and becomes sustainable." In fact, social entrepreneurship is reaching a point of maturity such that it is no longer a greenfield; there are often competing solutions to 
social problems, even if the solutions are older and less efficient. If a preexisting organization has greater size, reach and support, in comparison to a newer social startup, the more nascent firm might not be able to get meaningfully past the launch stage. Larger firms are also more likely to have economies of scale, allowing them to become more efficient and profitable as they grow, or for nonprofits, more financially sustainable. Alternatively, though, if a new SE demonstrates greater effectiveness, older and more established organizations might find their funding diverted to these newer, "hotter" firms. Finally, greater scale can lead to greater impact. As Bradach" notes: "It is no longer sufficient to simply scale what works in an incremental manner." Former US President Bill Clinton concurs: "Nearly every problem has been solved by someone, somewhere. The frustration is that we can't seem to replicate [those solutions] anywhere else." 10

Using inductive, qualitative research methods, ${ }^{11}$ our research uncovers many of the factors associated with social startups that have scaled. We add to our unique findings ${ }^{12}$ published management research in the fields of social entrepreneurship, strategy, and the management of organizations. Specifically, the book's eight chapters discuss how social entrepreneurs garnered and modified critical resources ${ }^{13}$ in order to position their startups for success in the first five years of their organization's life. These included the organization's human and financial capital, as well as decisions made by the founding team which influenced their marketing decisions, operations, and even the startup's organizational form. To this body of research we added case data from funders of SEs (i.e., Better Ventures and Bridges Fund Management), as well as best practices for new technology adoption by an organization that is both a funder and funded (i.e., Grameen America), to complete our final chapters on moving from idea, to pilot, to scale, and the role of technology in scaling.

In this book we use Bloom and Chatterji's ${ }^{14}$ definition of social entrepreneurs as individuals who start up and lead new organizations or programs that are dedicated to mitigating or eliminating a social problem, deploying change strategies that differ from those that have been used in the past. Our findings are based on in-depth interviews with social startups and the firms that fund them, based on the high caliber startup network affiliated with UC Berkeley, Stanford University, and the Massachusetts Institute of Technology (MIT), as well as other top universities that sent entrants through the Berkeley Haas' Global Social Venture Competition. ${ }^{15}$ On average, the eight companies featured in our research grew their revenue and employees upwards of 300 percent each year in their first five years, and their social impact over 500 percent each year during the same period of time. The organizations that participated in our research include: Back to the Roots, d.light, Embrace, Fair Trade USA, Kiva, Revolution Foods, Sanergy, and World of Good.

We began our initial research by asking a set of semi-structured interview questions on topics such as: the founding team, early employees, revenue traction, the process of piloting products (and pivoting products) and how the organization measured its social impact in years one through five. We also asked about the SE's source of funding and the amount of funds raised in the organization's first five years. We then asked more qualitative questions, focusing on how its products, customers, and distribution channels developed during the same period of time. We inquired about the role of service and/or product innovation in the startup's success. We also asked if national or local governments served as partners to the SEs 
by providing funding or other types of aid. Finally, we wanted to understand the importance of the organization's brand recognition and media attention in scaling. We closed our interviews by encouraging participants to elaborate on anything that we might have missed that played a pivotal role in their growth.

The summary of our findings is laid out across eight chapters that address the most important aspects of building an organization to scale. The first chapter focuses on how startups create a management team for growth, with an emphasis on building a dynamic and heterogeneous founding team. This is followed by the second chapter, which discusses how social startups can best create and curate a stakeholder network. In the third chapter we explore the types of financial capital that a social startup can obtain, intertwined with that startup's choice of organizational form (i.e., for-profit, nonprofit or hybrid organization). Based on our findings, an underrepresented area of discussion within the social sector is brand building. Therefore, in the fourth chapter we emphasize just how important it is to build and manage a startup's brand, including the benefits of becoming a "media darling."

In the book's fifth chapter we delve into how to move an idea from pilot to scale. Woven into Chapters 4 and 5 are also concepts now becoming mainstream in the field of entrepreneurship (and to some extent social entrepreneurship), including both design thinking and business modeling. The sixth chapter discusses how to develop and refine one's value chain (i.e., as defined by Michael Porter). ${ }^{16}$ This includes building both suppliers and distribution channels with alignment to mission. Our seventh chapter explores the pivotal role of technology in allowing firms to scale, referring to such firms as Grameen America and Kiva. We then end this book with an in-depth discussion on impact assessment, with a keen focus on what is most appropriate for early-stage firms.

In closing, we were motivated to write this book based on the success stories of many alumni from Berkeley Haas. These founders' social startups, in many cases, are well beyond their early years, but they are all still growing and pivoting ten to twenty years after founding. We also wrote this book to serve the next generation of students, who show increasing interest and passion around addressing social issues through business means, with the firms they have chosen to found and fund. We are grateful to the many graduate student researchers who have helped us collect in-depth data on the firms profiled over the years. They have also been a great resource in researching the broad array of publications around new firms, so that our work can reflect the learnings of practitioners, scholars and social scientists alike.

\section{NOTES}

1. Jelen, Jonatan. "Financial Sustainability for Social Entrepreneurship - Pragmatic or Social Imperative or Impractical Challenge?" Entrepreneurship and Innovation, vol. 10, no. 3, 2009, p. 209.

2. Bauman, Heiner. “The Growth Capital Market in the U.S.” Alliance, vol. 10, no. 1, 2005, pp. 37-9.

3. Harnish, Verne. Scaling Up. Gazelles, Inc., 2014, Ashburn, Virginia.

4. Phillips, Mary. "Growing Pains: The Sustainability of Social Enterprises." Entrepreneurship and Innovation, vol. 7, no. 4, 2006, pp. 221-30.

5. Ibid., p. 223. 
6. Bradach, Jeffrey. “Scaling Impact.” Stanford Social Innovation Review, Summer 2010, p. 27.

7. Nelson, Richard R., and Sidney G. Winter. "Evolutionary Theorizing in Economics." Journal of Economic Perspectives, vol. 16, no. 2, 2002, pp. 23-46.

8. Phillips, Mary. “Growing Pains: The Sustainability of Social Enterprises.” Entrepreneurship and Innovation, vol. 7, no. 4, 2006, p. 223.

9. Bradach, Jeffrey, and Abe Grindle. “Transformative Scale: The Future of Growing What Works." Stanford Social Innovation Review, vol. 4, 2004, pp. 1-13.

10. Olson, Lynn. Growing Pains: The Story of Summerbridge. John F. Kennedy School of Government, Case C16-94-1267.0, 1994, p. 2.

11. Strauss, Anselm, and Juliet Corbin. Basics of Qualitative Research. Sage Publications, Inc., 1998, Thousand Oaks, CA.

12. Walske, Jennifer, and Laura Tyson. “A Comparative Case Analysis, Assessing How Social Enterprises Scale.” International Journal of Entrepreneurship and Innovation, vol. 16, no. 4, 2015, pp. 269-81.

13. Barney, Jay B. "Organizational Culture: Can it be a Source of Contained Competitive Advantage." Academy of Management Review, vol. 11, no. 3, 1986, pp. 656-65.

14. Bloom, Paul N., and Aaron K. Chatterji. "Scaling Social Entrepreneurial Impact." California Management Review, vol. 51, no. 3, 2009, p. 114.

15. Gsvc.org.

16. Porter, Michael E. The Competitive Advantage: Creating and Sustaining Superior Performance. Free Press, 1985, New York, NY. 